\title{
ZASZCZEPIANIE CHRZEŚCIJAŃSTWA W KRAJACH ZACHODNIOSŁOWIAŃSKICH W ŚWIETLE KRONIKI THIETMARA (W ZARYSIE): W KRĘGU MYŚLI MISJOLOGICZNEJ I HISTORIOLOGICZNEJ DOBY LUDOLFINGÓW
}

\author{
STANISŁAW ROSIK \\ Wydział nauk historycznych i pedagogicznych, Uniwersytet Wrocławski \\ E-mail: stanislaw.rosik@uwr.edu.pl
}

\begin{abstract}
Inoculation of Christianity in the West Slavic Land from the Thietmar's Chronicle's Point of View (in Outline): in the Circle of Missionary and Historiographical Mind in the Period of Ludolfings

The author evaluates the information the Thietmar's Chronicle provides about the ongoing Christianization of the Slavic people at the turn of the first and second millennium. It summarises the terms and views of the chronicler, especially the view of the collective Christianization of the whole peoples. The article especially analyses Thietmar's view on the cases stressing the relations and transformations of the pre-christian (or non-christian) beliefs to the spreading Christianity. It seems that the key factor in perceiving certain people as Christians was for the chronicler the religion of their elites and working church administrative. Important role is dedicated to the bishops - colleagues of the writer Thietmar - who were responsible for the missionary efforts between the Slavs. Their work is at the focus point of the narrative.

Keywords: Thietmar's Chronicle; Christianization; mission; paganism; Poland; Bohemia; Slavs
\end{abstract}

Szczególna wartość przekazu Thietmara z Merseburga $(975-1018)^{1} \mathrm{w}$ badaniach nad początkami chrześcijaństwa w krajach Słowian Zachodnich wynika z faktu, iż znakomity kronikarz odwoływał się do „żywej” - nieprzekraczającej trzech pokoleń wstecz pamięci przedstawicieli swojego środowiska oraz współczesnych mu wiadomości, a co więcej, jako biskup sam stał w obliczu zadań misyjnych i duszpasterskich wśród ludności serbołużyckiej w obrębie jego diecezji. Znamiennie w tym kontekście brzmi w początkowych rozdziałach jego utworu polemika z poglądami kwestionującymi pośmiertny byt człowieka, którą skierował do ludzi niewykształconych („,inliterati”), a przede wszystkim do Słowian ${ }^{2}$.

1 Kronika Thietmara, tekst łaciński i polski, tłum., wstęp i komentarz Marian Zygmunt JEDLICKI. Poznań 1953 (dalej: Thietmar). O autorze i dziele zob. m. in. Marian Zygmunt Jedlicki, Wstęp, w: Ibidem, s. I-XXXI; Helmut LIPPELT, Thietmar von Merseburg: Reichsbischof und Chronist. Köln/Wien 1973, s. 46-137; Stanisław ROSIK, Interpretacja chrześcijańska religii pogańskich Słowian w świetle kronik niemieckich XI-XII wieku (Thietmar, Adam z Bremy, Helmold). Wrocław 2000, s. 43-60; Kerstin SCHULMEYER-AHL, Der Anfang vom Ende der Ottonen: Konstitutionsbedingungen historiographischer Nachrichten in der Chronik Thietmars von Merseburg. Berlin 2009.

2 Thietmar (I 14). 
Tak wskazany zbiorowy adresat tych wywodów siłą faktu przeczytać ich nie mógł, gdyż nie partycypował w kulturze pisma, a zatem miejsce to pozostaje uznać za przejaw autokreacji Thietmara jako nauczyciela i apologety kościelnego credo ${ }^{3}$. Można oczywiście hipotetycznie dopatrywać się w tym wypadku jakiegoś refleksu katechetycznej działalności kronikarza jako duszpasterza, jednakże jest to już tylko domysł. W świecie wykreowanym w kronice odesłanie do wyobrażeń religijnych Słowian i zachodzących w ich życiu przemian religijnych mogło bowiem następować nie tylko na podstawie odniesień do konkretnych działań i doświadczeń misjonarzy, lecz także - i to w pierwszym rzędzie - na zasadzie ogólnych kategoryzacji położenia społeczności zachodniosłowiańskich z perspektywy ówczesnej myśli misjologicznej i specyfiki interpretacji dziejów pod piórem Thietmara.

Zasadniczo zaprowadzanie chrześcijaństwa w narracji merseburskiego kronikarza ukazywane jest na dwóch poziomach: 1) całych zbiorowości - gentes - w zgodzie $\mathrm{z}$ wczesnośredniowieczną teologią misyjną ${ }^{4}$ korespondującą $\mathrm{z}$ literalnym rozumieniem ewangelicznych nakazów w wersji z Vulgaty: „docete omnes gentes, baptizantes eos”5; 2) konwersji indywidualnej za sprawą działalności misjonarzy, rudymentarnej katechezy i doprowadzania do chrztu. Nie braknie zatem w poniższych refleksjach odniesień do opisów działalności konkretnych osób - zwłaszcza biskupów Bosona, Wigberta, Jordana czy Reinberna - i instytucji na rzecz zaprowadzania chrześcijaństwa na ziemiach zachodniosłowiańskich, przy czym podstawowe znaczenie zyskają kategorie kulturowe, zwłaszcza doktrynalne, porządkujące świat przedstawiony.

Lektura twórczości Thietmara z Merseburga pod kątem tytułowego w tych rozważaniach zaszczepiania chrześcijaństwa w krajach zachodniosłowiańskich pozwoli nam zatem wykroczyć poza wydobywanie z narracji odpowiedniej materii zdarzeń i kreślenia ich biegu, by tym samym zagłębić się w sferę kultury umysłowej europejskich środowisk intelektualnych sprzed tysiąca lat, zwłaszcza w zakresie teologii misyjnej oraz interpretacji dziejów ${ }^{6}$.

\section{Gentes, quae suscepta christianitate... Pod parasolem chrześcijańskich monarchii: konwersja ludów (gentes)}

Samo objęcie plemiennych społeczności słowiańskich zwierzchnością chrześcijańskiej monarchii - bez względu na postęp indywidualnej konwersji - przesądzało o traktowaniu ich przez Thietmara jako włączonych do kręgu Christianitas, a w efekcie o przyjęciu przez nie chrześcijaństwa. Czytelnie obrazuje to opis rebelii Luciców (983), którzy zda-

\footnotetext{
Szerzej w tej sprawie ROSIK, Interpretacja chrześcijańska religii, s. $68 \mathrm{nn}$.

4 Zob. np. Brigitte WAVRA, Salzburg und Hamburg Erzbistumsgründung und Missionspolitik in karolinischer Zeit. Berlin 1991, s. $15 \mathrm{nn}$.

5 Zob. Mt 28, 29; por. Biblia Sacra juxta Vulgatam Clementinam. Editio electronica, wyd. Michael TWEEDALE. London 2005, s. 1286.

6 Pozwoli to rozwinąć tezy przedstawione - po części szerzej w odniesieniu do strategii I praktyki misyjnej - w artykule: Stanisław ROSIK, Chrystianizacja Połabia i Pomorza (X-XII w.): zarys procesu oraz strategii i praktyki misyjnej. Część I, w: Historia Slavorum Occidentis. Czasopismo Historyczne, 14/3 (2017), s. 68-88.
} 
niem kronikarza wszczęli ją „po przyjęciu chrześcijaństwa” („suscepta christianitate”)7, zrzucając nie tylko władzę cesarstwa, lecz także - oczywiście w ocenie teologicznej - porzucając służbę Chrystusowi i św. Piotrowi ${ }^{8}$. Tymczasem proces konwersji indywidualnej u tych ludów, o ile w ogóle został zapoczątkowany, to zaszedł najwyżej na tak nikłą skalę, że nieuchwytną w wymiarze źródeł.

W następnym po Thietmarze pokoleniu kronikarz Wipo celnie podsumował w odniesieniu do Luciców przebieg tej historii: „niegdyś pół-chrześcijanie przez apostacki

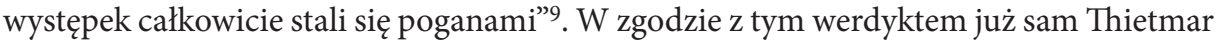
przedstawia Luciców jako pogan (gentiles, m.in. W bardzo cennym dla badań nad religią Słowian ekskursie o świątyni w Radogoszczy ${ }^{10}$ ). Warto też podkreślić zakwalifikowanie przez Wipona ich postępowania jako apostazji, gdyż taki pogląd najpewniej podzielał też Thietmar. Analogicznie bowiem potraktował Obodrytów i Wagrów, po ich rebelii z 1018 r. nazywając ich apostatami ${ }^{11}$.

W tej optyce zatem apostazja całych zbiorowości mogła skutkować ponownym uznawaniem ich za pogan, a więc odmiennie niż w wypadku konwersji indywidualnej, a ściśle chrztu, którego teologia zakłada niemożność zatarcia jego duchowych skutków i tym samym nie pozwala uznać apostaty ponownie za poganina ${ }^{12}$. Upadek władzy cesarstwa i sprzężonych z nim instytucji kościelnych na Północnym Połabiu w drugiej dekadzie XI w. stał się więc faktem, trwałym zwłaszcza w odniesieniu do kręgu lucickiego, co niosło przekonanie o repoganizacji tamtejszych społeczności. Niemniej ten stan nie oznaczał likwidacji biskupstw w wymiarze instytucjonalnym - znamiennie brzmi w tym kontekście nazwanie współczesnego Thietmarowi starogardzkiego biskupa Bernarda: „apostatae istius gentis (...) episcopus”, a zatem „biskup tego apostackiego ludu”13.

W wypadku z kolei trwania struktur chrześcijańskiej monarchii i Kościoła w danym kraju nawet ewidentne przejawy rodzimego kultu przedchrześcijańskiego na jego obszarze kronikarz opisywał już nie w kategoriach obcej religii, ale jako występki przeciw chrześcijaństwu. Podobnie też ludność mieszkająca na ziemiach objętych organizacją kościelną, choć wciąż przywiązana do rodzimych wierzeń i kultów, nie jest już określana w jego dziele mianem pogan, ale niepiśmiennych („inliterati”), prostaków czy głupców ${ }^{14}$.

Z drugiej natomiast strony Thietmar charakteryzuje tę ludność jako „powierzoną" (commissi) biskupom, co celnie koresponduje z przedstawianym wypełnianiem przez nich - o czym szczegółowo poniżej - typowych dla biskupa zadań z zakresu tzw. cura

7 Thietmar (III 17): „Gentes, quae suscepta christianitate regibus et inperatoribus tributarie serviebant...."

8 Thietmar (III 17): „Vice Christi et piscatoris eiusdem venerabilis Petri varia demoniacae heresis cultura deinceps veneratur". Szerzej w tej sprawie: ROSIK, Interpretacja chrześcijańska religii, s. 85-90.

9 Wiponis Gesta Chuonradi II imperatoris, wyd. Harry BRESSLAU (MGH Scriptores rerum Germanicarum in usum scholarum separatim editi. Vol. 61). Hannover/Leipzig 1915, s. 52 (Kap. 33): „olim semichristiani per apostaticam nequitiam omnino sunt pagani".

10 Thietmar (VI 23).

11 Ibidem (VIII 6): apostata gens.

12 Warto tu podkreślić, że samo określenie „poganin” (paganus, gentilis) jest już interpretacją chrześcijańską wyznawcy nie-monoteistycznej religii, a sięga w wypadku gentilis tradycji biblijnej (upowszechnioną zwłaszcza dzięki Vulgacie).

13 Wspomnianych już Obodrytów i Wagrów - Thietmar (VIII 6).

14 Czytelny przykład to postawa ,inliterati” ze Słowianami na czele (zob. przyp. 2), a więcej przykładów poniżej w charakterystyce postawy diecezjan Reinberna czy dwuwierczych czcicieli źródła Głomacz bądź idola o imieniu Hennil. 
animarum („troski o dusze”): formowali oni podległe im wspólnoty chrześcijańskie przez nauczanie często od podstaw i stąd nie dziwi ich bezpośrednie zaangażowanie w likwidację sanktuariów pogańskich i doprowadzanie całych grup ludności do chrztu, a także budowanie dla niej kościołów. W czynnościach tych realizowano dwa zasadnicze w perspektywie teologicznej aspekty praktyki misyjnej: abrenuntiatio diaboli - unicestwienie pogaństwa w życiu publicznym, oraz confessio fidei - ustanowienie instytucjonalnej obecności Kościoła w życiu zbiorowym ${ }^{15}$.

Kluczowe znaczenie miało w wypadku wdrażania w życie społeczne tych utrwalonych już od starożytności idei misjologicznych uprzedzające działalność biskupstw zaangażowanie władzy monarszej w proces chrystianizacyjny. W zgodzie $\mathrm{z}$ tym ludy tworzące wspólnotę chrześcijańską (Christianitas) w ujęciu kronikarza są w pierwszej instancji, "powierzone” monarchom ${ }^{16}$. Oni też, z cesarzem na czele, odgrywają na kartach jego dzieła pierwszoplanową rolę w fundowaniu i utrzymywaniu sieci diecezjalnej. Pod parasolem ich władzy rozpocząć się mogła działalność ewangelizacyjna i duszpasterska prowadzona paralelnie do anihilacji rodzimych kultów i wierzeń słowiańskich, której szczegółowe opisy odnoszą się do południowego Połabia oraz władztwa Piastów.

\section{In oriente innumeram Christo plebem predicacione assidua et baptismate vendicavit... Konwersja Słowian „,na wschodzie” Rzeszy Ludolfingów. Od Bosona do Thietmara}

Spektakularne przykłady realizacji misyjnych procedur przynoszą opisy działań biskupów Merseburga, poprzedników Thietmara, Bosona oraz Wigberta. Pierwszy z nich zasłynął swymi wysiłkami na rzecz konwersji Słowian jeszcze jako mnich klasztoru św. Emmerama w Ratyzbonie, co ostatecznie dało mu tron nowo założonej diecezji merseburskiej, na którym zasiadał jedynie dwa lata - zmarł w 970 r. Thietmar nie określa ściśle obszaru jego misyjnej działalności, sytuując ją ogólnie „na Wschodzie” 17 . Za tym, że prowadził ją najpewniej w strefie serbołużyckiej, można domniemywać, uwzględniając podaną w tym kontekście wiadomość, iż wybudował on kościół, położony w miejscowości nazwanej od jego imienia, a zatem najpewniej w Posa koło Żytyc ${ }^{18}$.

Co więcej, Boso nie tylko wybudował kościół dla nawracanych Słowian, ale nawet miał zapisywać słowiańskie słowa, by skuteczniej ich nauczać, a wkładał wiele wysiłku, by przyswoili sobie śpiew Kyrie eleison. Daremnie, gdyż Słowianie mieli przekręcać formułę, by brzmiała nonsensownie: „w krzu olcha” („ukriwolsa”) ${ }^{19}$, co niekiedy traktuje

15 Zob. np. Marian RECHOWICZ, Chrzest Polski a katolicka teologia misyjna we wczesnym średniowieczu, w: Ruch Biblijny i Liturgiczny 19 (1966), s. 67-74.

16 Celnie obrazuje ten sposób myślenia kronikarza sformułowanie we wzmiance o zwycięstwie Ottona I w bitwie nad rzeką Lech (955), iż cieszyła się z niego „cała społeczność chrześcijańska, a najbardziej powierzona królowi” - „omnis christianitas, maximeque regi commissa” (por. Thietmar II 10).

17 Thietmar (II 36): „,in oriente innumeram Christo plebem predicacione assidua et baptismate vendicavit".

18 Ibidem. Zob. też przyp. wydawcy.

19 Ibidem (II 37): „Hic ut sibi commissos eo facilius instrueret, Sclavonica scripserat verba et eos kirieleison cantare rogavit exponens eis huius utilitatem. Qui vecordes hoc in malum irrisorie mutabant 
jako dojście do głosu religijności rodzimej w potraktowaniu obcej modlitwy ${ }^{20}$. Trudno jednakże wykluczyć tu opinię samego Thiemara, który wprost stwierdza, że "głupcy" złośliwie przekręcali Kyrie, by szydzić z ich apostoła ${ }^{21}$. Sam fakt, że próbował on uczyć ich modlitwy, wskazuje, że już wcześniej udało mu się doprowadzić nauczanych do chrztu, a w zbudowanym dla nich kościele celebrować $\mathrm{z}$ ich (jak widać, raczej niechętnym) udziałem nabożeństwa.

Opis wysiłków Bosona nie przynosi więc całościowego obrazu procedury misyjnej, natomiast przykuwa uwagę kilkoma jej szczegółami, zwłaszcza próbami docierania do umysłów Słowian przez nauczanie pochrzcielne w ich języku. Boso korzystał pod tym względem zapewne z doświadczeń kościelnego kręgu salzburskiego w misjach słowiańskich ${ }^{22}$. Dla Thietmara zaś stanowił on bardzo aktualny przykład do naśladowania, zwłaszcza że podległa kronikarzowi jako biskupowi ludność w znacznej mierze wciąż wykazywała silne przywiązanie do przedchrześcijańskich kultów plemiennych, głównie w odniesieniu do sacrum upostaciowanego w przyrodzie.

Bezpośredni poprzednik Thietmara, merseburski biskup Wigbert (1004-1009), w kraju podległego mu plemienia Chudziców (Chutici), odciągając ustawicznym nauczaniem „powierzonych” sobie od „błędu bałwochwalstwa”, wyciął otaczany kultem gaj zwany „Świętym Borem” (Zutibure), by na jego miejscu wznieść kościół²3. Ten przykład - znanej już od czasów chrystianizacji Anglosasów - adaptacji przedchrześcijańskich miejsc kultowych dla potrzeb kościelnych ${ }^{24}$ rysuje się jako klasyczna realizacja wspomnianych już zakresów działań w ramach tzw. abrenuntiatio diaboli i confessio fidei w życiu społecznym, zwłaszcza przy wysoce prawdopodobnym założeniu, że ów „Święty Bór” stanowił bądź mieścił centralne sanktuarium całego plemienia analogicznie np. do gaju Prowego w ziemi Wagrów 25 .

Niekiedy jednak wyrugowanie kultu odnoszącego się do elementów krajobrazu nie mogło nastąpić na zasadzie likwidacji sanktuarium, na co dobrym przykładem jest opisana przez Thietmara cześć, jaką plemię Głomaczy okazywało wobec źródła, od którego wzięli swą nazwę, czyli Głomacz. W rozlewisku źródła ukazywać się miały znaki wróżeb-

Ukrivolsa, quod nostra lingua dicitur: aeleri stat in frutectum, dicentes: 'Sic locutus est Boso', cum ille aliter dixerit".

20 Dopowiedzenie, iż „tak powiedział Boso” („sic locutus est Boso”) miałoby np. W opinii nawracanej ludności chronić ją przed gniewem rodzimych bogów (tak np. W eseistycznym ujęciu Zofia KOSSAK-SZCZUCKA, Troja Pótnocy. Warszawa 1986, s. 69) albo alternatywnie stanowić np. próbę wzmocnienia siły modlitwy przez wspomnienie Bosona jako orędownika do Boga chrześcijańskiego - szerzej w tej sprawie: ROSIK, Interpretacja chrześcijańska religii, s. 84 .

21 Zob. przyp. 18.

22 Zob. Franz ZAGIBA, Das Geistesleben der Slawen im Frühen Mittelalter. Wien/Köln/Graz 1971, s. 123, 141 nn.; a także np. Wojciech MROZOWICZ, Początki kultury pisma na Słowiańszczyźnie zachodniej, w: Stowiańszczyzna w tworzeniu Europy (X-XIII/XIV w), red. Stanisław Rosik. Wrocław 2008, s. $29-42$.

23 Thietmar (VI 37): „Predicacione assidua commissos a vana supersticione erroris reduxit, lucumque Zutibure dictum, $\mathrm{ab}$ accolis ut Deum in omnibus honoratum et ab evo antiquo numquam violatum, radicitus eruens, sancto martiri Romano in eo ecclesiam construxit".

24 Zob. list Grzegorza Wielkiego do opata Melitona - Gregorius Melito Abbati in Franciis, w: Gregorii I papae Registrum epistolarum. Libri VIII-XIV, wyd. Ludwig HARTMANN (MGH Epistolae. Vol. 2). Berlin 1899, s. 331 (XI 56).

25 Szczegółowy opis - z autopsji odnośnie do 1156 r. - sporządził Helmold z Bosau w latach 60. XII w. - zob. Helmoldi presbyteri bozoviensis Chronica Slavorum, wyd. Bernhard SCHMEIDLER (MGH Scriptores rerum Germanicarum in usum scholarum separatim editi. Vol. 32). Hannover 1937 (I 84). 
ne zwiastujące przyszłość plemiennej wspólnoty - krew i popiół wojnę, a żołędzie i zboża urodzaj - co przesądzało o wysokiej atrakcyjności tej wodnej hierofanii ${ }^{26}$. Kronikarz ubolewa, iż mieszkańcy kraju żywią wobec niej większy lęk i cześć niż wobec kościołów, podkreślając przy tym złudność ich nadziei ${ }^{27}$. Tym samym jego przekaz wyraźnie potwierdza wystąpienie na południowym Połabiu charakterystycznego dla wczesnego etapu chrystianizacji zjawiska synkretyzmu religijnego, a w tym wypadku współwystępowanie liturgii kościelnej paralelnie do wciąż funkcjonujących przedchrześcijańskich miejsc kultowych.

Inny wymiar zjawiska tej tzw. dwuwiary przedstawia Thietmar, wzmiankując cześć oddawaną przez ludność wiejską, często hipotetycznie identyfikowaną jako słowiańska, „bóstwom domowym” (domestici dei), na co przykład stanowi szczegółowo opisany kult idola opiekuńczego o imieniu Hennil ${ }^{28}$. W tym wypadku jednak liczyć się należy nie tylko z przetrwaniem przedchrześcijańskiej idolatrii, ale także już z ewentualną kontynuacją rodzimego zwyczaju otaczania czcią duchów opiekuńczych domu i zagrody albo też kultywowania pamięci o zmarłych przodkach już w formie wykształconej w czasach kontaktów z chrześcijaństwem i to pod pewnym wpływem obecnej w nim symboliki władczej bądź liturgicznej. Byłby to już przejaw kształtowania się pierwocin religijności ludowej, typowej dla społeczeństw oficjalnie już schrystianizowanych ${ }^{29}$.

Wspomniane tu opisy fenomenów tzw. dwuwiary Thietmar sporządził w odniesieniu do otoczenia mu bliskiego, być może znanego mu z autopsji i własnej praktyki duszpasterskiej. Te niuanse dotyczące codziennego bytowania dopiero chrystianizowanych środowisk nie przykuły już jednak jego uwagi w wypadku ziem z dalszego sąsiedztwa, podległych monarchii pierwszych Piastów. Zawarty w jego dziele materiał na jej temat daje kapitalny przykład modelowego ujęcia włączenia konkretnego kraju i ludu do społeczności Christianitas w kategoriach reprezentowanej przez kronikarza historiologii.

\section{Et protinus caput suum membra populi subsequuntur... Polacy za Mieszka I i Bolesława Chrobrego}

Opis oblężenia Niemczy w 1017 r. przez wojska cesarza Henryka II w trakcie jego wojny Bolesławem Chrobrym, stał się okazją do dygresji o pochodzeniu nazwy Silensi, kraju, w którym leżał ów gród. Otóż otrzymać ją miał od wielkiej góry - mowa o Ślę-

26 Thietmar (I 3); por. ROSIK, Interpretacja chrześcijańska religii, s. 64-68. W sprawie kultu Głomacza zob. Jacek BANASZKIEWICZ, Źródło Głomacz i jego rajska okolica, w: Viae historicae: księga jubileuszowa dedykowana Profesorowi Lechowi A. Tyszkiewiczowi w siedemdziesiata rocznice urodzin, red. Mateusz Goliński - Stanisław Rosik. Wrocław 2001, s. 407-414; Jerzy STRZELCZYK, Mity, podania $i$ wierzenia dawnych Stowian. Poznań 2007, s. 74 n.

27 Thietmar (I 3): „źródło Głomacz omnis incola plus quam aecclesias, spe quamvis dubia, veneratur et timet".

28 Według Thietmara (VII 69) idol miał kształt laski, z którą krążył od domu do domu pasterz, wzywając jego opieki: „Czuwaj, Hennilu, czuwaj!”.

29 Takiej ocenie kultu Hennila może sprzyjać kształt idola. Według Thietmara na lasce go upostaciowującej znajdowała się ręka trzymająca żelazny pierścień, co można odczytać jako nawiązanie do kształtu insygniów władzy, może nawet kościelnej (pastorał, pierścień, ręka jako odpowiednik manus Dei). Jednakże uniwersalność występowania takich symbolicznych atrybutów nakazuje uznać tego rodzaju propozycje interpretacyjne jedynie za domysł, znajdujący alternatywę w odwołaniu do symboliki $\mathrm{z}$ kręgu sięgającej przedchrześcijańskich pokładów kultury rodzimej. 
ży - otaczanej „niegdyś” (olim) ogromną czcią przez mieszkańców tej ziemi, mianowicie w czasach, gdy tam kultywowano "przeklęte pogaństwo" ${ }^{30}$. Z przekazu wynika więc, że kult ów należy już do przeszłości kraju Ślężan - to do tego plemienia odsyła nazwa Silen$s i^{31}$ - co w odniesieniu do ogółu jego mieszkańców musi budzić wątpliwości. Wystarczy wziąć pod uwagę z jednej strony słabość stopnia zaawansowania konwersji indywidualnej na tych ziemiach, a z drugiej ogromną atrakcyjność góry jako hierofanii i niemożność wyrugowania jej kultu z przestrzeni społecznej na takiej zasadzie jak np. posągu, świątyni czy świętego gaju.

Podobnie w wiadomości Thietmara o zabijaniu wdów słowiańskich podczas obrzędów pogrzebowych męża, wątpliwość budzi podkreślenie, iż zwyczaj ten praktykowano w kraju ojca Bolesława Chrobrego, Mieszka I, w czasach, gdy był on poganinem ${ }^{32}$, co sugeruje, iż po jego chrzcie już nie. Trudno wszak wyrugować w krótkim czasie utrwalony od pokoleń rytuał. Kluczowe znaczenie w egzegezie tego miejsca, podobnie jak wspomnianego wątku ślężańskiego, ma zatem uwzględnienie specyfiki oglądu prezentowanego przez kronikarza. Od razu uderza w tym wypadku traktowanie kraju Silensi czy całego władztwa Piastów jako chrześcijańskich, ale zastanawia, dlaczego kronikarz zdecydował się umiejscowić w przeszłości przedchrześcijańskie praktyki kultowe, jak rytuały funeralne czy cześć wobec góry. Ich obecność w wypadku - ewidentnie chrześcijańskich w jego ujęciu - ziem diecezji wschodnioniemieckich nie została wszak pominięta ${ }^{33}$. Skąd zatem tak „wyidealizowany” obraz konwersji współczesnej Thietmarowi Polski?

Wydaje się, iż specyfikę tego podejścia kronikarza celnie pozwala wyjaśnić odniesienie do jego wizji konwersji Mieszka I i jego ludu. Najpierw dziejopis podkreśla zasługi czeskiej małżonki Piasta, Dobrawy, w przekonaniu go do nawrócenia, w czym odnaleźć można realizację toposu mulier suadens ${ }^{34}$. Motyw ten uwznioślałby dość schematyczny, nasycony dozą liturgicznego patosu, opis przyjęcia chrześcijaństwa przez Mieszka i jego poddanych. Za władcą jako „głową” bowiem iść miały do chrztu „ułomne członki ciała”,

30 Thietmar (VII 59): „Posita est autem haec in pago Silensi, vocabulo hoc a quodam monte nimis excelso et grandi olim isibi indito; et hic ob qualitatem suam et quantitatem, cum execranda gentilitas ibi veneraretur, ab incolis omnibus nimis honorabatur".

31 W tłumaczeniach kroniki Thietmara notorycznie traktuje się miano „Silensi” w odniesieniu do Śląska (zob. np. Thietmari Merseburgensis Episcopi Chronicon, wyd. Werner TRILLMICH. Darmstadt 1992, s. 421 (VII 59); Ottonian Germany: the Chronicon of Thietmar of Merseburg, tłum. David A. WARNER. Manchester/New York 2001, s. 350), niekiedy nawet jako ablativus od łac. przymiotnika Silensis „śląski” (tak JEDLICKI w: Thietmari VII, 59), co wydaje się bezzasadne, gdyż Thietmar nie tylko nie odmieniał przez przypadki tego rodzaju nazw ludów i krajów słowiańskich (zob. np. Thietmar [I 4]: „in pago Chutizi dicto”; [IV 45]: „ad Diedesisi pagum” itd.), lecz także z racji anachronicznego uznania kraju Ślężan już za Śląsk. Owszem, historyczna kraina nad Odrą nawiązuje do etnonimu Ślężan, ale traktowanie ich jako Ślązaków jest przedwczesne, a przy tym nie sposób potwierdzić, by ich kraj nazywano Śląskiem na etapie plemiennym. Szerzej w tej sprawie zob. The formation of Silesia (to 1163): Factors of regional integration, w: The long formation of the Region Silesia (c. 1000-1526), red. Przemysław WISZEWSKI. Wrocław 2013, s. 55 nn.

32 Thietmar (VIII 3).

33 Zinterpretowanych jednak w kategoriach grzechu, występku przeciw doktrynie kościelnej, zob. wyżej o działalności biskupów merseburskich Bosona oraz Wigberta.

34 Thietmar (IV 56) „... crebro dilectae uxoris ortatu innatae infidelitatis toxicum evomuit et in sacro baptismate nevam originalem detersit”. Zob. np. Jerzy BANASZKIEWICZ, Dąbrówka „christianissima” i Mieszko poganin (Thietmar, IV 55-56; Gall, I 5-6), w: Nihil superfluum esse: prace z dziejów średniowiecza ofiarowane Profesor Jadwidze Krzyżaniakowej, red. Józef Dobosz - Jerzy Strzelczyk. Poznań 2000, s. 85-93. 
czyli reszta ludu ujętego jako jeden organizm ${ }^{35}$. Kronikarz nie pominął jednak milczeniem, że pierwszy biskup tej wspólnoty, Iordan, mocno się namordował, zanim „słowem i czynem” doprowadził jej członków „do uprawiania niebiańskiej winnicy”36.

Zwłaszcza na podstawie badań archeologicznych podkreśla się, iż brak dostatecznych przesłanek za uznaniem konwersji poddanych Mieszka I w ciągu kolejnych dekad jego panowania za zjawisko masowe ${ }^{37}$, a zatem opis Thietmara uformowania się wspólnoty chrześcijańskiej w Polsce na czele z władcą oraz współpracującym z nim biskupem z perspektywy całości kraju Piastów pozostaje uznać za nadmiernie optymistyczny. Rzecz w tym jednak, że najpewniej intencją kronikarza nie było odnoszenie się do ogółu mieszkańców władztwa Mieszka I czy Bolesława Chrobrego, ale do węższej społeczności ściśle związanej z kręgiem władzy, złączonej przestrzeganiem wspólnych norm prawa i obyczaju, a przede wszystkim respektującej w jednym „pakiecie” zwierzchność monarchii i biskupów.

Tak postrzegana społeczność Polaków (Poleni) dominowała nad plemionami w ramach władztwa wczesnopiastowskiego (m.in. wspomnianymi Ślężanami - krajem Silensi) i choć sama była tak jak one słowiańska, to z perspektywy kronikarza kluczowe znaczenie w jej oglądzie miała jej przynależność do systemu politycznego i kościelnego skupionego wokół cesarstwa. Thietmar traktował więc Polaków analogicznie do Sasów władających, bądź jedynie roszczących sobie pretensje do władania, ludami połabskimi. W literackiej kreacji ów lud Mieszka I i Bolesława Chrobrego okazuje się też gospodarzem na ziemiach plemion im podległych i nie przypadkiem np. ponosi ciężar obrony kraju Silensi. Rzeczywiście można w zgodzie z narracją kronikarza uznać, iż dla tej części poddanych Piastów praktyki takie jak kult góry czy rytualne uśmiercanie wdów należały już do przeszłości.

Polacy jednak w opinii Thietmara pozostał nie wykazywali się gorliwością w respektowaniu wymagań nowej wiary i to nawet w kolejnym po chrzcie Mieszka I pokoleniu. Kronikarz podkreśla, iż do zwyczajowych kar - jak okrutne okaleczenia za cudzołóstwo doszły też nowe, jak wyłamywanie zębów za nieprzestrzeganie postów, a praktykowano je z nakazu Bolesława Chrobrego, gdyż tylko w ten sposób władca mógł zyskać posłuch poddanych. Zaznaczając, że biskupi nie są zwolennikami takich metod chrystianizacji, osobiście jednak Thietmar uznał je za godne pochwały (choć okrutne) właśnie ze względu na twardość charakteru tego ludu przyrównanego do upartego osła ${ }^{38}$.

Merseburski biskup nie odmawiał zatem obu pierwszym Piastom na polskim tronie zasług w krzewieniu chrześcijaństwa, co stanowiło jaśniejszy rys ich wizerunku na kartach kroniki, zwłaszcza w odniesieniu do Bolesława Chrobrego, któremu w innych kontekstach narracji nie szczędził wyrazów niechęci ${ }^{39}$. Ganił nawet samego cesarza Ot-

35 Thietmar (IV 56): „Et protinus caput suum et seniorem dilectum membra populi hactenus debilia subsequuntur et nupciali veste recepta inter caeteros Christi adoptivos numerantur".

36 Ibidem: „Iordan, primus eorum antistes, multum cum eis sudavit, dum eos ad supernae cultum vineae sedulus verbo et opere invitavit".

37 Niedawno np. Przemysław URBAŃCZYK, Co się stało w roku 966?. Poznań 2016, s. 137 n.

38 Thietmar (VIII 2): „... sunt multae consuetudines variae; et quamvis dirae, tamen sunt interdum laudabiles. Populus enim suus more bovis est pascendus et tardi ritu asini castigandus et sine poena gravi non potest cum salute principis tractari".

39 Np. ibidem, (V 56), gdzie mowa o narodzinach Bolesława - wprawdzie z zacnej matki, ale jako sprawcy nieszczęścia wielu matek. 
tona III za to, że podniósł rangę polskiego władcy, czyniąc go „z trybutariusza panem”40. Na ogół łączy się wzmiankę o tym awansie z postanowieniami zjazdu gnieźnieńskiego, na którym doszło do ustanowienia metropolii gnieźnieńskiej, co istotne w majestacie prerogatyw cesarza rzymskiego. Istnienie odrębnej prowincji kościelnej utwierdzało pozycję Polski w kontekście międzynarodowym ${ }^{41}$.

Zbiorowość „Polaków” (Poleni) potraktowana została więc przez kronikarza jako lud oporny, ale ostatecznie posłuszny władcy, co istotne, także odnośnie do zasad chrześcijaństwa. Tym samym religia ta stała się w poglądzie Thietmara elementem tożsamości tego ludu, co jednak - zwłaszcza w perspektywie kryzysu piastowskiej państwowości i upadku związanej z nią organizacji kościelnej w latach 30. XI w. - wskazuje na pewien prymat w narracji Thietmara sfery idei nad ścisłym odniesieniem do opisywanych faktów społecznych. Dopiero odnowa polskiej monarchii po tym jej załamaniu przyniosła uformowanie się zbiorowości Polaków na kształt ukazany przez Thietmara, co nastąpiło na zasadzie kilkupokoleniowego poszerzania wspólnoty złączonej nie tylko zwierzchnością państwową, ale i więzią religijną.

\section{In populo nimis insulso, sanctae predicacionis plantacionem eduxit... Biskup kołobrzeski Reinbern nad Bałtykiem}

Warto zaznaczyć, że według Thietmara arcybiskupstwo gnieźnieńskie powstało kosztem uszczuplenia metropolii magdeburskiej. Jej sufraganami mieli być Jordan i Unger, który zdaniem dziejopisa nie wyraził zgody na utworzenie metropolii w podległym dotąd jego diecezji kraju Piastów. Mimo tego uchybienia kronikarz wyraził nadzieję, iż arcybiskupstwo utworzono zgodnie z prawem ${ }^{42}$, co pozwoliło mu też z aprobatą spojrzeć na założenie i obsadę trzech podporządkowanych wówczas Gnieznu biskupstw w Krakowie, Wrocławiu i Kołobrzegu (ściśle „Salsa Cholbergiensis”) ${ }^{43}$. Biskup tej ostatniej, położonej nad Bałtykiem, diecezji, Reinbern ${ }^{44}$, zyskał nietuzinkowe upamiętnienie na kartach kroniki, a lakoniczny opis jego działań misyjnych przynosi kwintesencję modelowego ujęcia zaszczepiania chrześcijaństwa w odniesieniu do ziem objętych już zwierzchnością chrześcijańskiej monarchii.

Przed rokiem 1000 terytorium diecezji kołobrzeskiej podlegało kościelnie Ungerowi, niemniej jej utworzenie w narracji Thietmara rysuje się nie jako reorganizacja sieci ko-

${ }^{40}$ Ibidem, (V 10).

41 Warto w tym kontekście przypomnieć, że Thietmar (VI 92), odnotował też płacenie „czynszu” na rzecz św. Piotra przez Bolesława Chrobrego, co potwierdza jego wysoki, przysługujący np. królom, status w relacjach z Rzymem, a ściśle z papiestwem.

42 Thietmar (IV 45): cesarz „fecit ibi archiepiscopatum, ut spero, legitime”. Kompleksowo w sprawie założenia metropolii gnieźnieńskiej zob. zwłaszcza Roman MICHAŁOWSKI, Zjazd gnieźnieński: religijne przesłanki powstania arcybiskupstwa gnieźnieńskiego. Wrocław 2005; a także Dariusz Andrzej SIKORSKI, Kościół w Polsce za Mieszka I i Bolesława Chrobrego: rozważania nad granicami poznania historycznego. Poznań 2011, s. 332-486 (o proteście Ungera, s. 468 nn.).

43 Thietmar (IV 45). Unger jako biskup poznański zdaniem Thietmara nie został podporządkowany metropolicie Radzimowi. Zob. też niżej, przyp. 45.

44 Reinbern ocalał przed niepamięcią jedynie dzięki wzmiankom Thietmara. O Reinbernie w świetle przekazu Thietmara, z uwzględnieniem literatury zagadnienia, zob. Stanisław ROSIK, Conversio gentis Pomeranorum: studium świadectwa o wydarzeniu (XII wiek). Wrocław 2010, s. 21-44; Karol KOLLINGER, Polityka wschodnia Bolesława Chrobrego. Wrocław 2013, s. 35 nn., 45 nn. 
ścielnej, ale kształtowanie jej od podstaw w nadmorskim środowisku. Według Thietmara Reinbern nie tylko niszczył ogniem sanktuaria pogańskie („fana idolorum”), ale też dokonał swoistego „chrztu” morza: z intencją przepędzenia mających je zamieszkiwać demonicznych istot pokropił fale wodą święconą i wrzucił w nie cztery namaszczone świętym olejem kamienie ${ }^{45}$. Kreatywny (intencjonalny) cel tych działań kronikarz definiuje precyzyjnie: dzięki nim Reinbern „zaszczepił na nieprzynoszącym owocu drzewie nową gałąź dla wszechmocnego Pana, to znaczy pośród ludu nader głupiego założył uprawę świętego głoszenia [słowa bożego]" 46 .

Podjęte z intencją anihilacji obecności pierwiastków antisacrum czynności Reinberna miały zatem przygotowywać grunt pod ustanowienie „tu i teraz” Kościoła partykularnego założonego wcześniej - najpewniej już podczas zjazdu gnieźnieńskiego ${ }^{47}$ - metaforycznie ukazanego jako „uprawa świętego przepowiadania”, a także jako nowa „szczepka” czy "gałąź" na dotąd niedającym owocu drzewie, jakim okazuje się „lud nader głupi”. Uderza w tym sformułowaniu swoiste oddzielenie instytucji Kościoła od nauczanego ludu, pośród którego zostaje ona - pozostając w kręgu metaforyki Thietmara - zaszczepiona. Kapitalnie ów obraz oddaje sytuację początków chrześcijaństwa w środowisku społecznym de facto wciąż przywiązanym do rodzimych wierzeń i kultów.

Ludność tę kronikarz określa jako „powierzoną” Reinbernowi, a pejoratywne nazwanie jej ludem głupim, tępym czy nieokrzesanym (insulsus) wskazuje, iż - podobnie jak wcześniej Jordan - kołobrzeski biskup nie miał łatwego zadania jako nauczyciel. Trudził się on zatem nad formowaniem nowej wspólnoty eklezjalnej, podejmując wysiłki na rzecz konwersji indywidualnej. Działał zatem podobnie jak wspomniani już Boso, a zwłaszcza Wigbert, usuwając sanktuaria i kulty przedchrześcijańskie z obszaru własnej diecezji. Jednakże kazus Reinberna pozwala pełniej uwydatnić zakres teologicznego znaczenia tzw. abrenuntiatio diaboli, a kluczowe znaczenie w tym wypadku ma rytuał oczyszczenia morskiego żywiołu ze złych mocy.

Można wprawdzie domyślać się, że z jednej strony Reinbern starał się zwalczać pogańskie sacrum, stając w obliczu stanowiącego naturalne zjawisko w wypadku nadmorskiej społeczności kultu wód, a z drugiej zaś strony, że oddawał pod opiekę chrześcijańskiego Boga ów morski żywioł jako życiodajny dla nawracanej ludności (ryby i sól stanowiły podstawę jej dobrobytu) ${ }^{48}$. Warto jednak przede wszystkim przypomnieć, że morze, jego słone odmęty, w symbolice chrześcijańskiej upostaciowuje mityczny odwieczny chaos, siły destrukcji zagrażające stworzeniu o diabolicznym obliczu ${ }^{49}$ i to przeciw nim kierował się wszak ryt wykonany przez Reinberna.

Nie sposób precyzyjnie określić, jakie dokładnie teologiczne poglądy uwarunkowały kształt tego aktu w wydaniu Reinberna, natomiast przytoczona wyżej wykładnia Thiet-

45 Thietmar (VII 72): „Fana idolorum destruens incendit et mare demonibus cultum inmissis quatuor lapidibus sacro crismate perunctis et aqua purgans benedicta novam Domino omnipotenti propaginem in infructuosa arbore, id est in populo nimis insulso, sanctae predicacionis plantacionem eduxit”.

46 Ibidem: „...novam Domino omnipotenti propaginem in infructuosa arbore, id est in populo nimis insulso sanctae predicacionis plantacionem, eduxit".

47 W pierwszej wzmiance Thietmara o Reinbernie w opisie zjazdu gnieźnieńskiego mowa ściśle o podporządkowaniu go rządcy ufundowanej wówczas metropolii (IV 45), a o samym założeniu diecezji kołobrzeskiej kronikarz milczy. Trudno jednak wskazać mocne przesłanki za tezą, by doszło do tego przed zjazdem w Gnieźnie, szerzej o tym zob. ROSIK, Conversi gentis Pomeranorum, s. $28 \mathrm{n}$.

48 ROSIK, Conversio gentis Pomeranorum, s. 23, 26.

49 Zob. np. Dorothea FORSTNER, Świat symboliki chrześcijańskiej. Warszawa 1990, s. 65 n., 133, 436. 
mara wyraźnie wskazuje na jego założycielski charakter albo przynajmniej założycielski kontekst w odniesieniu do instytucji Kościoła. Z tym kierunkiem interpretacji koresponduje symbolika namaszczonych kamieni, która odsyła do obrazu samego Chrystusa jako skały bądź też kamienia węgielnego Kościoła ${ }^{50}$. Z kolei liczba tych kamieni, cztery, przywołuje symbolicznie uniwersum (czterostronność świata, pełnię itd.). Rytuał wyraża zatem ideę zaprowadzenia nowego ładu w wymiarze kosmicznym - panowania Boga po ujarzmieniu chaosu, przepędzeniu sił diabolicznych.

Nowa diecezja wyznacza więc w tym kontekście zakres panowania Chrystusa, a cztery kamienie stanowią symboliczne fundamenty tego nowego ładu w jej obrębie lub też jedynie stawiają tamę mocom chaosu, znacząc granicę objętego boską protekcją kosmosu. Oba rozwiązania w wymiarze symbolicznej interpretacji wzajemnie się nie wykluczają, a ich wspólny mianownik w postaci kosmologicznego odniesienia pozwala uwydatnić, iż abrenuntiatio diaboli rozumiane jako likwidacja przybytków i kultów pogańskich to (jedynie) aspekt intencjonalnej eliminacji sił zła z ekumeny, wpisany w szerszy kontekst wyobrażeń, obejmujący wymiar kosmologiczny. Tym samym także ustanawianie diecezji zyskuje w interpretacji Thietmara walor zagospodarowania nowej przestrzeni tak społecznej (tu: „populus insulsus”), jak też naturalnej, które w perspektywie teologicznej dokonuje się na zasadzie jej sakralizacji.

\section{Rekapitulacja}

W świetle przekazu Thietmara zaprowadzanie chrześcijaństwa zarówno na Połabiu, jak też w Polsce w X i na początku XI w. następowało zasadniczo w ramach tego samego modelu działań uwarunkowanego wspólną teologią misji. Objęcie danego obszaru zwierzchnością chrześcijańskiej monarchii i związanych z nią struktur kościelnych skutkowało traktowaniem zamieszkujących go społeczności (gentes) już jako włączonych do kręgu Christianitas, a członkowie tych plemiennych zbiorowości traktowani byli jako ludność „powierzona” władcom i biskupom. Na pierwszych - z cesarzem na czele - spoczął obowiązek budowania i utrzymywania struktur kościelnych, a na drugich doprowadzanie do konwersji i duszpasterstwa w wymiarze indywidualnym.

Zasadnicza różnica między Polską a Połabiem w narracji Thietmara zaznacza się natomiast w odniesieniu do władzy zwierzchniej patronującej przedsięwzięciom chrystianizacyjnym. W wypadku Połabia objęli ją przedstawiciele elity wschodniofrankijskiej, a następnie cesarstwa Ludolfingów, głównie Sasów, podporządkowując bądź eliminując słowiańską starszyznę. Zatem chrystianizacja rozpoczęła się tu jako skutek poszerzenia na ziemie słowiańskie struktur władztwa wschodniofrankijskiego (niemieckiego), już od pokoleń chrześcijańskiego. Nawracanie społeczności połabskich dokonywało się więc jako element rozwoju już chrześcijańskiej monarchii, uformowanej co najmniej od czasów karolińskich (można tu jednak sięgnąć wstecz czasów Chlodwiga).

W wypadku Polski Thietmar kreśli ów proces od początku: chrzest Mieszka I wyznacza moment narodzin nowego ludu chrześcijańskiego (za „głową” idą „członki ciała”), który zostaje uformowany przez wysiłki pierwszego biskupa, Iordana, a przez władców

50 Ibidem, s. 126-130, $172 \mathrm{nn}$. 
wciąż utrzymywany jest w posłuchu, także w sprawach religii. Społeczność tę, nazywając ją mianem Polaków (Poleni), kronikarz traktuje już jako chrześcijańską, a pełni ona w jego ujęciu rolę analogiczną do odgrywanej przez Sasów dla ziem połabskich, zatem przynajmniej de facto ${ }^{51}$ - nie stanowi ogółu poddanych pierwszych Piastów.

Tym samym pod parasolem ich władzy prowadzone były według Thietmara działania analogiczne do tych, które opisał w odniesieniu do strefy serbołużyckiej, w tym własnej diecezji mersburskiej, na co czytelny przykład stanowi działalność kołobrzeskiego biskupa Reinberna. I on, i merseburski Wigbert, już w ramach istniejącej diecezji likwidowali przedchrześcijańskie sanktuaria i kulty, jednakże traktowane nie jako pogańskie, ale jako bałwochwalcze. W tej perspektywie ich przedchrześcijańska geneza nie jest podkreślana, a traktuje się przywiązanie do nich w kategoriach grzechu popełnianego przez osoby czy całe społeczności należące już do Christianitas.

Ta przynależność mogła ustać dopiero po zrzuceniu zwierzchności chrześcijańskiej monarchii, traktowanym zarazem $\mathrm{w}$ teologicznej ocenie na zasadzie apostazji, jako porzucenie służby Chrystusowi, co czytelnie obrazują opisy rebelii Luciców (983) czy Obodrytów i Wagrów (1018). Nawet faktyczny kres funkcjonowania biskupstw na ziemiach Słowian w takich sytuacjach nie oznaczał ich likwidacji w wymiarze teologiczno-instytucjonalnym. Kościół partykularny w ujęciu Thietmara to byt zakorzeniony najpierw sferze mistycznej i strukturach władzy organizujących ład Christianitas, a następnie dopiero zaszczepiany w przestrzeni społeczno-terytorialnej chrystianizowanych krajów.

Celnie oddają ten sposób oglądu nawiązujące do tradycji biblijnej metafory wyrażające sposób umiejscowienia Kościoła w społecznym kontekście dopiero nawracanej ludności: „uprawa słowa bożego” pośród „głupiego ludu”, „nowa gałąź dla Pana” na „nieowocującym dotąd drzewie”. Mówiąc o Kościele partykularnym, diecezji, Thietmar koncentruje się więc nie tyle na wspólnocie wiernych, ile na instytucji i znakach jej obecności w świecie. Koresponduje z tym stosowanie przez Thietmara metafory sponsa Christi - odmiennie niż w kontekście nowotestamentalnym ${ }^{52}$ - w odniesieniu do kamiennej katedry, która tym samym symbolizuje całość diecezji ${ }^{33}$.

Z perspektywy historiologicznej włączanie do społeczności Christianitas całych ludów (gentes) na zasadzie obejmowania ich zwierzchnością chrześcijańskich monarchii rysuje

51 Trudno ostatecznie rozstrzygnąć, czy kronikarz jedynie ściśle koncentrował się na wspólnocie Polaków w wymiarze religijnym, czy też rzeczywiście oddzielał ją od reszty poddanych Piastów, traktowanych na zasadzie plemion podległych Polakom i ich władcom. To drugie rozwiązanie lepiej tłumaczy przedstawianie pogaństwa jako przeszłości w dziejach władztwa Piastów w odniesieniu do rytuałów funeralnych czy kultu Ślęży.

52 Taka interpretacja związku Chrystusa z Kościołem (zob. np. 2 Kor 11, 2; Ef 5, 22-32) odsyła przede wszystkim do wymiaru duchowej wspólnoty wiernych. Porównanie Kościoła do budowli z kamieni ma oczywiście również nowotestamentowe wzory, a mowa w tym wypadku o ludziach jako żywych kamieniach (1 P 2, 5). Trudno jednak upatrywać w tym wypadku jakiegoś ścisłego nawiązania do tego obrazu w wypadku wspomnianej tu metaforyki Thietmara.

53 Zob. np. wzmiankę Thietmara (VI 60) o konsekracji katedry w Bambergu: „Peracta in civitate Bavenbergensi aecclesia maiore, cum natalicius regis dies esset [et XXXV. iam inciperet annus], II. Non. Mai omnis primatus ad dedicationem istius aulae ibidem congregatur; et sponsa haec Christi per manus [Iohannis patriarchae de Aquileia et aliorum plus quam XXX episcoporum] consecratur". Szerzej o kategorii sponsa Christi w ujęciu Thietmara zob. Stanisław ROSIK, Sponsae Christi oraz dii manu facti w Kronice Thietmara: elementy konwencji dziejopisarskiej w służbie historiologii, w: Viae historicae, red. Goliński - Rosik. Wrocław 2001, s. 415-421. 
się w dziele Thietmara jako rozszerzanie królestwa Boga w świecie. Liczyła się dlań jednak podległość ludów nie tylko Chrystusowi, ale św. Piotrowi, co wskazuje na obowiązki cesarstwa i królestw (a tym samym poddanych im gentes) wobec Rzymu papieskiego.

W wypadku zaś zaprowadzania chrześcijaństwa na poziomie biskupstw przykuwają uwagę najpierw działania mające przynieść anihilację sił zła działających tak w wymiarze kultów uznanych za bałwochwalcze, jak też samej natury (likwidacja sanktuariów pogańskich, egzorcyzmowanie elementów przyrody i żywiołów), a następnie ustanowienie na obszarze diecezji placówek kościelnych połączone z rytualną sakralizacją jej przestrzeni aż po wymiar kosmologiczny.

W ten sposób powstawał odpowiedni kontekst społeczny i terytorialny dla realizacji zadań misyjnych i duszpasterskich podejmowanych w pierwszym rzędzie przez samych biskupów (cura animarum). Nawet zakładając na podstawie wzmianek Thietmara masowość udzielanych wówczas chrztów ludności słowiańskiej, trudno nie zauważać, że w przeważającej mierze tkwiła ona co najwyżej w dwuwierze. Traktowanie tej ludności jako chrześcijańskiej wynika więc przede wszystkim z koncentracji autora na instytucjonalno-ideowym oglądzie rozwoju Christianitas i sieci kościelnej.

Wyłaniający się z dzieła Thiemara obraz zaszczepiania chrześcijaństwa u Słowian Zachodnich ma więc w odniesieniu do opisywanych stosunków społeczno-religijnych w znacznym stopniu walor normatywny. Tym samym więc kronikarz nie tyle fałszował stan wiedzy o faktycznym rozwoju chrześcijaństwa na Połabiu czy w Polsce, co nieraz mu się zarzuca ${ }^{54}$, ile kształtował rzeczywistość w dwojakim wymiarze: nie tylko bowiem świata przedstawionego w tekście, lecz także środowiska powstania i pierwotnego odbioru jego twórczości (Sitz-im-Leben), przyczyniając się do promowania w nim idei i postaw sprzyjających postępom chrystianizacji w krajach zachodniosłowiańskich.

\section{BIBLIOGRAFIA}

\section{Źródła}

Biblia Sacra juxta Vulgatam Clementinam. Editio electronica, wyd. Michaele TVVEEDALE. London 2005. Gregorii I papae Registrum epistolarum. Libri VIII-XIV, wyd. Ludwig HARTMANN (MGH Epistolae. Vol. 2). Berlin 1899.

Helmoldi presbyteri bozoviensis Chronica Slavorum, wyd. Bernhard SCHMEIDLER (MGH Scriptores rerum Germanicarum in usum scholarum separatim editi. Vol. 32). Hannover 1937.

Kronika Thietmara, tekst łaciński i polski, tłum., wstęp i komentarz Marian Zygmunt JEDLICKI. Poznań 1953.

Ottonian Germany: the Chronicon of Thietmar of Merseburg, tłum. David A. WARNER. Manchester/ New York 2001.

Thietmari Merseburgensis Episcopi Chronicon, wyd. Werner TRILLMICH. Darmstadt 1992. Wiponis Gesta Chuonradi II imperatoris, wyd. Harry BRESSLAU (MGH Scriptores rerum Germanicarum in usum scholarum separatim editi. Vol. 61). Hannover/Leipzig 1915.

\section{Literatura}

Jerzy BANASZKIEWICZ, Dąbrówka „christianissima” i Mieszko poganin (Thietmar, IV 55-56; Gall, I 5-6), w: Nihil superfluum esse: prace $z$ dziejów średniowiecza ofiarowane Profesor Jadwidze Krzyżaniakowej, red. Józef Dobosz - Jerzy Strzelczyk. Poznań 2000, s. 85-93.

\footnotetext{
54 Zob. wyżej przyp. 37.
} 
Jacek BANASZKIEWICZ, Źródło Głomacz i jego rajska okolica, w: Viae historicae: księga jubileuszowa dedykowana Profesorowi Lechowi A. Tyszkiewiczowi w siedemdziesiąta rocznicę urodzin, red. Mateusz Goliński - Stanisław Rosik. Wrocław 2001, s. 407-414.

Dorothea FORSTNER, Świat symboliki chrześcijańskiej. Warszawa 1990.

Karol KOLLINGER, Polityka wschodnia Bolesława Chrobrego. Wrocław 2013.

Zofia KOSSAK-SZCZUCKA, Troja Pótnocy. Warszawa 1986.

Helmut LIPPELT, Thietmar von Merseburg: Reichsbischof und Chronist. Köln/Wien 1973.

The long formation of the Region Silesia (c. 1000-1526), red. Przemysław Wiszewski. Wrocław 2013.

Roman MICHAŁOWSKI, Zjazd gnieźnieński: religijne przesłanki powstania arcybiskupstwa gnieźnieńskiego. Wrocław 2005.

Wojciech MROZOWICZ, Początki kultury pisma na Słowiańszczyźnie zachodniej, w: Słowiańszczyzna w tworzeniu Europy (X-XIII/XIV w), red. Stanisław Rosik. Wrocław 2008, s. 29-42.

Marian RECHOWICZ, Chrzest Polski a katolicka teologia misyjna we wczesnym średniowieczu, w: Ruch Biblijny i Liturgiczny 19 (1966), s. 67-74.

Stanisław ROSIK, Chrystianizacja Połabia i Pomorza (X-XII w.): zarys procesu oraz strategii i praktyki misyjnej. Część I, w: Historia Slavorum Occidentis. Czasopismo Historyczne, 14/3 (2017), s. 68-88.

Stanisław ROSIK, Conversio gentis Pomeranorum: studium świadectwa o wydarzeniu (XII wiek). Wrocław 2010.

Stanisław ROSIK, Interpretacja chrześcijańska religii pogańskich Słowian w świetle kronik niemieckich XI-XII wieku (Thietmar, Adam z Bremy, Helmold). Wrocław 2000.

Stanisław ROSIK, Sponsae Christi oraz dii manu facti w Kronice Thietmara: elementy konwencji dziejopisarskiej w służbie historiologii, w: Viae historicae, red. Goliński, Mateusz - Rosik, Stanisław. Wrocław 2001, s. 415-421.

Kerstin SCHULMEYER-AHL, Der Anfang vom Ende der Ottonen: Konstitutionsbedingungen historiographischer Nachrichten in der Chronik Thietmars von Merseburg. Berlin 2009.

Dariusz Andrzej SIKORSKI, Kościół w Polsce za Mieszka I i Bolesława Chrobrego: rozważania nad granicami poznania historycznego. Poznań 2011.

Jerzy STRZELCZYK, Mity, podania i wierzenia dawnych Słowian. Poznań 2007.

Przemysław URBAŃCZYK, Co się stało w roku 966?. Poznań 2016.

Brigitte WAVRA, Salzburg und Hamburg Erzbistumsgründung und Missionspolitik in karolinischer Zeit. Berlin 1991.

Franz ZAGIBA, Das Geistesleben der Slawen im Frühen Mittelalter. Wien/Köln/Graz 1971. 